\title{
Tobacco Cultivation and Trade in Kavalla and the Ottoman Financial Policy: A Case of Financial Growth in the Late Ottoman Empire
}

\author{
Dimitrios Stergiopoulos \\ History Department, University of California in San Diego, Leiden, Netherlands \\ Email: dimstergio@yahoo.gr
}

Received 7 January 2016; accepted 12 April 2016; published 15 April 2016

Copyright (C) 2016 by authors and Scientific Research Publishing Inc.

This work is licensed under the Creative Commons Attribution International License (CC BY). http://creativecommons.org/licenses/by/4.0/

C) (i) Open Access

\begin{abstract}
The purpose of this paper is to relate the growth of Kavalla as a region of tobacco cultivation and as an exporting port with the structural reforms in the economy and other fields of social life in the Ottoman Empire. These undertaken reforms are necessitated by empire's weakness to compete with the increasingly dominant European states and by the spread of nationalism's destabilizing influence in the Balkans. In this context, I show that the regional growth of Kavalla in 19th century is linked with Ottoman Empire's incorporation into the global economy of expanding capitalism as a supplier of raw materials for the European industries. The effects of these reforms in the social reality of this provincial city are approached through the changes that occurred in the sphere of economic activities and state policies, the improvement of the transportation network, taxation and landownership and the social structure through the rise of new strata.
\end{abstract}

Keywords

Tobacco, Kavalla, Macedonia, Ottoman Empire, 19th Century, Modernizing Reforms

\section{Introduction}

The purpose of this study was to investigate the influence of Ottoman state policy and modernizing reforms in the growth of Kavalla in the 19th century as an exporting port of agricultural products. In the complex relation between the central authorities of a vast empire with its regions, the state policies were not fixed but were a matter of contestation among the central and local elites. In the case of Kavalla, whether the state modernizing 
policies was the main cause for the city's growth was an open question. Moreover, there was a need to examine whether the state intended to transform the region into an exporting port, and the way in which its policies affected the local social and economic life.

I approach these questions through a historical perspective that focuses on the financial policy of the empire and through studies on the history of Kavalla region and eastern Macedonia. In a sense, I attempt to ground those empire-wide policies at a local level but also to contextualize the changes in local social and economic life as events that take place in a vast empire that is under a radical program of modernization, westernization and empowerment of central authority.

The effect of a policy, that is been decided in the capital, can vary considerably from region to region. The universal implementation of state policies is a matter of contestation and an issue of profound importance in the empire's path towards modernization. In a sense, this is one of the ultimate goals of the Ottoman state machine in 19th century and it comes in sharp contrast with its past. The Ottomans' approach until then is to facilitate and respect regional particularities and differences, as long as its subjects recognize the political unity of the empire, pay their taxes and honor their obligations (Yavuz, 2013: p. 35). This mentality has allowed major differences in the evolution of local societies (Hershlag, 1968: p. 9). The differences between Macedonia and southeast Anatolia, a mountainous and mostly Kurdish speaking region with primitive productive means, are striking though both were part of the same empire.

Until the 1970s, the dominant paradigm in Ottoman historiography was the theme of the empire's decline after its golden era in the 15th and 16th century (Lewis, 2001a, 2001b). Although this interpretation offered a satisfactory explanation for its weakness vis-á-vis Europe since 18th century, it failed to account for its survival until WWI. Moreover, the long 19th century was an era of growth for certain regions in the empire, including its capital. Thus, the late Ottoman society and empire is a case of a multinational cosmopolitan society that, at times, flourishes through its incorporation into the global sphere of expanding capitalism. If the case of Kavalla is seen in this context, the very idea of decline has to be recast as the failure of the Ottoman state to influence and to benefit from regional growth. Although the main theme of its policy throughout the 19th century was to centralize and to increase the presence of the state in everyday life, this was only partially accomplished with respect to the task of achieving an adequate increase in its tax revenues.

I also need to say a word on why I choose Kavalla and tobacco to illuminate the effects of state modernizing reforms in Ottoman regional social reality. As I Illustrate in what follows, tobacco could not have its prominent role in the growth of that area before the incorporation of Ottoman economy into the expanding capitalism of the time. The rapid industrialization of European economy, alongside the increase in the buying power of its consumers and precisely because of the lower costs of industrial goods, demanded specialization of the regions in its periphery in so far as the supply of raw materials was concerned. This specialization allowed specific products, such as tobacco, to be produced at lower costs due to advantageous climate conditions and because of the farmers' specialization in its cultivation. The advances in transportation means, particularly the use of steam in maritime trade, further lowered the transportation costs, an event that further propelled these imports.

These events changed the status of the Ottomans for Europe's Great Powers and transformed into a field of competing interests. Furthermore, it was one of the first instances in which Europe became involved in a region that was not under its direct political control, as was the case with the colonies. Those changes set the agenda for the Ottoman's modernizing reforms. The Ottoman state had two conflicting aims: to strengthen its own presence vis-à-vis the European powers and to facilitate their interests in order to secure their support as it went through a phase of gradual decline. Neither of the two was pursued to the end and depending on the period, one of the two would become more prominent as a direct result of the shifts in the relations between the empire and its European counterparts.

This incorporation had drastic effects upon Kavalla's social reality. The investment in the transportation network, the emergence of various social classes, such as a large working class, a significant middle class whose members worked in the commercial sector of the city, and the rise of a "bourgeois class with certain autonomy in their interests in comparison with those of the state elites" or the major landowners, would have been impossible before its growth in the 19th century from tobacco exports and state reforms.

Some basic facts about the region are necessary before I move on to the main part of my paper. Kavalla is one the main cities in eastern Macedonia and Thrace, in an area that is now part of Greece. It was one of the strategic locations for the control of the area between Thessaloniki (Selanik) and Istanbul (Constantinople) since the Byzantine Empire. The main road in the area, called Egnatia since Roman times, connected Thessaloniki to Istan- 
bul and crossed the plains north of Kavalla avoiding the hills that surrounded the city. Its natural port provided relatively safe mooring and served as the main port to the island of Thasos. The agricultural products from the fertile hinterland could be transported through Kavalla and other neighboring ports to the main urban centers in the Ottoman Empire and beyond. ${ }^{1}$

\section{Historical Background}

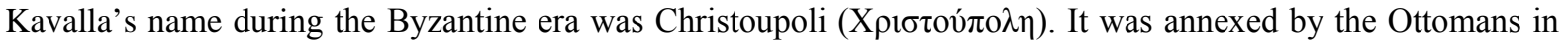
1391 and probably was completely destroyed. Sultan encouraged city's repopulation in the 15th century by locals and nomads from Anatolia and the city took on its present name. During the reign of Suleiman the Magnificent in the 16th century, walls and an aqueduct were constructed in the city and the mines' operation in Paggaio Mountain resumed; acts that improved city's security, provided more opportunities for its habitats and boosted its population (Stefanidou, 2007: pp. 29, 38, 44-45).

Until the mid-19th century, the city was considerably smaller than the other cities in the area such as Drama and Serres (Siroz)) and most of its inhabitants were Muslims. Muhammad Ali Pasha, the famous governor of Egypt, grew up in the city and left in the early 19th century to fight Napoleon's army in Egypt (Stefanidou, 2007: pp. 82-84). The city was the capital of a Sancak ${ }^{2}$, but until the 18th century it did not have its own governor and was part of the bigger and richer sancak of Thessaloniki. It was ruled by a sub-governor with the titles of mütesellim or müsellim ${ }^{3}$ and dizdar ${ }^{4}$ who was appointed by the Pasha ${ }^{5}$ of Thessaloniki.

The decentralization of the empire and the strengthening of the ayan ${ }^{6}$ during the 18th century had a significant impact on the area. The plains and the much larger cities in the north, such as Drama and Serres, were ruled by local notables, known as bey, and were only nominally controlled by the sub-governor in Kavalla (Stefanidou, 2007: p. 87). In the beginning of the 19th century, the heyday for the ayan and bey, Ismail Bey controlled a large part of the region from his headquarters in Serres. Only Kavalla, its port and the neighboring hinterland were controlled by the Pasha of Thessaloniki and his sub-governor in the city. Other powerful ayan in the area were Tirsinikli Ismail and Alemdar Mustafa Pasha. In contrast to other $a_{y a n}{ }^{7}$. Ismail Bey never opposed the imperial authority but cooperated with it in order to further consolidate his position. The Malikane $e^{8}$ system, which allowed them to appropriate part of the state tax revenues, was a decisive factor for their ascendance as semi-autonomous governors vis-a-vis central authority (Hanioğlu, 2008: pp. 6-7, 17, 60). The Janissaries' ${ }^{\text {'9 }}$ revolt and the establishment of a new Sultan in 1807 brought an end to attempts for closer control of the ayan by the previous ruler, Selim II, and the Sultan's authority was curtailed in the capital and the neighboring provinces. The area of Kavalla and Eastern Macedonia became an arena of competition among the various regional governors until the 1820s and the end of the Janissaries' corps (Hanioğlu, 2008: p. 55).

The Malikane system was used extensively for the area's important sources of revenue such as the foundry in Eleftheroupoli (Pravi), the mines in the mountain of Paggaio and the customs at the port of Kavalla. Among the responsibilities of the foundry's lessor was to send a certain number of projectiles in the imperial shipyard in Istanbul (Stefanidou, 2007: pp. 93-95). Apart from regular taxes on agricultural production, such as the tithe, part of the agricultural production had to be sold to the state in fixed and below market prices because of its proxim-

\footnotetext{
${ }^{1}$ Places' names appear in the language of the country that they belong to today but I give their Turkish names after the first mention. Turkish terms are translated and for non-translated words in italics, I include a brief description in the footnotes.

${ }^{2}$ Sancak was an administrative division in the ottoman administrative system until 19th century and its size is comparable to today's provinces or prefectures.

${ }^{3}$ Military commander.

${ }^{4}$ Garrison commander.

${ }^{5}$ Governor.

${ }^{6}$ Local notables and governors, the closest of a landed aristocracy that existed in the Ottoman Empire.

${ }^{7}$ The most famous case in the area was the powerful Tepeleneli Ali Pasa, governor of Janina, Ipeiros, and South Albania who resisted the Sultan's authority until the 1820s.

${ }^{8}$ Initially used in the eastern provinces of the empire, Malikâne was a taxing system that became the norm in 18th and 19th century. A source for revenue was auctioned by the state to the highest bidder. This was initially on an annual basis but gradually it was extended for the duration of the lessor's life. In certain cases, the lessors' descendant continued to exploit the source of revenue and to establish hereditary rights.

${ }^{9}$ This was a professional military unit, usually an infantry, which was instrumental in the earlier expansion of the Ottomans. The needs of modern warfare and the Janissaries' incorporation into the urban economy as protectors of the guilds and as shop owners, alongside their unruly attitude towards the central authority, undermined their importance in the battlefield and they were disbanded in 1826. Usually, and especially in the early Ottoman Empire, recruitment occurred through the devşirme or what is known as the child-gathering system from the Christian populations, although the corps were open to Muslims as well.
} 
ity to Istanbul. Many of the provinces in the Balkans, including the autonomous regions of Moldavia and Walachia, had similar obligations and secured Istanbul's supply of food and raw materials (Hanioğlu, 2008: p. 8).

The unstable financial environment and the low demand for agricultural products in Europe did not permit a permanent presence of merchants and sub-consulates in Kavalla. Until the 1820s, when the Austrian and the Greek state began its representation in the region and a small number of trade firms began operating, attempts by the French in the 18th century to establish a permanent trade and consular representation were not successful. In contrast to the city's future specialization in tobacco, until the 1830s the main exporting products also included cereals, wool and cotton. The area's obligations notwithstanding, one third of the production of cereal was exported, mostly through smuggling. The small growth of trade encouraged the presence of foreigners in the city and a small local bourgeoisie of Christian merchants and Muslim landowners appeared (Stefanidou, 2007: pp. 99-102). Nevertheless, the city could not have grown further without the liberalization of the economy in the 1840s. Until then, the state had as its main aim to provide goods to the capital and to other urban centers and to discourage export and long-distance trade through high custom duties. This policy would protect the traditional social order, with the bureaucracy at the top and the regional governors beneath it. Only in specific cases, social groups such as merchants, guilds and peasants could influence the implemented policies according to their interests (Hanioğlu, 2008: p. 20) (Pamuk, 2000: p. 10).

\section{Kavalla's Growth as an Exporting Port, 1839-1913}

\subsection{The Economic Sphere}

In the last period of the Ottoman Empire from 1839 until 1913, the city changed radically and from an insignificant regional port with limited commercial activity it became one of the biggest exporting ports in the empire and the Balkans. The specialization of the area in tobacco cultivation, manufacture and exports transformed its social reality in the area around the city and to a lesser extent the region of East Macedonia and Thrace. This transformation is a perfect case of the drastic effects from the incorporation of the Ottoman Empire into the global economy (McCarthy, 1995: p. 5).

The Ottoman's financial policies were not uniform throughout the period. During the initial period and under the strong influence of French and English advisors, free-trade liberalism was followed by limited interference from the state. Subsequently (1860-1908) limited protection was provided to Ottoman manufacturers. Only under the rule of Committee of Union and Progress (CUP) (1908-1918) was there an attempt to create a national economy through protectionist state policies (Quataert, 1994: pp. 761-764).

The financial agreements of 1838 and 1839 between the Ottoman Empire and all the major European powers signaled Europe's increasing involvement in Ottoman internal politics. These agreements were demanded in exchange for Europe's military help against the uprising of the semi-autonomous governor of Egypt, Muhammed Ali, who nevertheless remained nominally a tributary of the Sultan. According to these agreements, the state abolished its monopolies in agricultural products, and removed the barriers to European trade activities by making them liable to the same fees and taxes. This signified a change in the aims of Ottoman financial policy. From prioritizing the autarky of its economy by discouraging exports, it shifted to promoting exports of agricultural products and raw materials and the imports of manufactured goods. For tobacco and other agricultural products, export duties gradually decreased, until they became tax-free. Local consumption (ruhsatiye) and Retail trade (ihtisabiye) taxes were introduced for consumption in the domestic market (Stefanidou, 2007: p. 179). Because of these changes, the trade deficits sharply increased while the state introduced new silver and gold coins and ended the practice of debasement with the ultimate aim to create a centralized, monetary economy. This led to a crisis in the manufacturing sector and the empire's economy in general. The state's attempts to soften the impact by raising custom duties for imports and to control the adoption of European nationalities by its Christian merchants, because of the financial and legal privileges that Europeans enjoyed in the empire, were partially successful. It had falsely expected that the income from increased production and trade volume would offset the losses from the abolition of monopolies and lower customs. A permanent problem until the empire's dissolution was the need to cover the expenses of a constantly growing modernized state mechanism and army (Hanioğlu, 2008: pp. 47, 67, 69, 70). Widespread corruption among the lessors and local officials and an inefficient tax system, due to a chronic scarcity of trained personnel for the state machine, did not allow the state to fully benefit from the trade activity in Kavalla and only half of the expected revenues reached the central treasury (Stefanidou, 2007: p. 200). 
After the liberalization of state economic policy through the trade agreements of 1839 and 1840, the trade value, of which $80 \%$ was exports, grew by $600 \%$ in the period of $1857-1912$. The agreements had set the import custom duties at $3 \%$ and the export at $12 \%$, while trade within Sultan's dominion was tax free (French-Ottoman Trade Treaty, 1839). Although in the middle of the century, the port's trading activity was more or less similar to other ports in the area, such as Orfanos, Porto Lagos and Keramoti, it gradually became the main port and began competing, especially in exports, with the much larger port of Thessaloniki. Important agricultural products of the area, such as wool and cereals had been replaced by cotton and tobacco by the 1860s. Demand for cotton fell sharply after the end of the American civil war, which had blocked the import of cotton by the European textile industries. The area's specialization continued and almost led to a monoculture at the beginning of 20th century. In 1912, 90\% of the exports were tobacco and only a small amount of Kavalla's production, approximately 7\% in 1911, was channeled to the domestic market (Hanioğlu, 2008: p. 47) (Stefanidou, 2007: pp. 169-171, 174-175) (Pamuk, 2000: p. 205).

The default of the Ottoman Empire in 1875 led to the establishment of the Public Debt Administration (PDA) in 1881, known as "Düyun-u Umumiye-i Osmaniye Varidat-ı Muhassasa İdaresi" or "Düyun-u Umumiye" for short in Ottoman Turkish, so that part of the imperial revenues could be disposed for the repayment of the public debt. Part of the PDA's plan was the establishment of state monopolies in key products, including tobacco. "Co-Interesee de tabacs de l' Empire Ottoman", or simply Regie, was founded in 1884 and was owned by the Ottoman Bank ${ }^{10}$, German and Austrian funds, the PDA and the Ottoman state. It had the monopoly in the domestic market for tobacco products and it was also active in tobacco exports. Moreover, it had the right to collect revenues associated with the tobacco trade. Through those benefits it dominated the empire's domestic market and replaced the small and independent merchants who were active until then. Its effects were apparent in the manufacturing sector when it began setting up rolling-cigarette factories in the empire's big cities including Istanbul, Thessaloniki, Trabzon and Izmir, a development that led to the demise of the small private tobacco factories. Nevertheless, it fell short of estimated profits and in 1908 doubts were raised about whether it should continue as a monopoly (Stefanidou, 2007: pp. 176-177) (Hanioğlu, 2008: p. 135).

Regie never dominated the export trade that was gradually controlled by private or state monopolies from other countries and the city's tobacco firms. In the beginning of this period, the merchants would appear after the completion of the tobacco's processing and the trade would take place through local merchants, representatives of trade firms from Thessaloniki and domestic and foreign monopoly committees ${ }^{11}$. The high cost of tobacco's preliminary processing, its proper packaging and increasing demand led to the creation of specialized trade corporations and Société Anonymes. From the 1860s and 1870s onwards, new warehouses and trade facilities in the city were constructed. The most important trade partners were Austria and France. Although England and Russia never absorbed the same volume of tobacco, they were important trade partners until the beginning of 20th century when the American tobacco companies bought huge quantities of tobacco through the creation of trust companies. Those practices led twice to severe crises in the tobacco industry, high unemployment and strikes (Stefanidou, 2007: pp. 177-178, 196).

Some of the major foreign tobacco companies were included the: Commercial Company of Salonica Ltd. (A Jewish trade firm from Thessaloniki which moved its headquarters to London), Regie, Oriental Tobacco Trading Company (an Austrian firm owned by M. L. Herzog et Cie), N. Mayer et Cie. Ltd (English), American Tobacco Company, Schinasi Bros. (American) and the Macedonian Tobacco Company Ltd. (Greek). Moreover, local inhabitants, mostly Greeks, founded their own trading companies. Though much smaller, they would mediate among foreign companies and tobacco producers and some of them exported directly to foreign markets. Another lucrative activity for the locals was the construction and the leasing of tobacco warehouses to trade firms because only the largest exporting companies could afford to build their own warehouses. Many of those merchants were also bankers, moneylenders and represented insurance companies as well as foreign consular authorities (Stefanidou, 2007: p. 197).

The growth of external trade also affected imports by monetizing the local economy. Tobacco could not cover the basic needs of the producers. This, alongside the creation of a middle and upper class in the city that could afford a more luxurious lifestyle, increased the demand for imported goods. The port functioned mainly as an exporting port and locals were mostly served through trade fairs in Serres and Nevrokopi. The goods in those

\footnotetext{
${ }^{10}$ The Ottoman Bank, despite its name, was privately owned enterprise by French and English funds that also functioned as the empire's state and national bank.

${ }^{11}$ Tobacco was a state monopoly throughout Europe and could not be traded freely.
} 
fairs would arrive through the port of Thessaloniki and the Balkan land trade routes through Nis, Belgrade and Sofia. The imports in the port of Kavalla increased but their importance was always secondary. In the imports sector, English, French and Austrian interests dominated the market, especially the latter through the use of the Balkan land trade routes (Stefanidou, 2007: pp. 179-181).

The specialization in tobacco exports among other agricultural goods did not allow the creation of a local industrial sector (Hanioğlu, 2008: p. 23). The mine and foundry in the area ceased to operate in middle of 19th century and most of the manufacturing activity came from the cottage industry. The increase of the custom duties by $8 \%$ in 1861 and a 15-year exemption from customs for new industries in the import of capital goods led to minor industrial growth from 1870 onwards. This was reinforced by the turn to protectionism by the state and structural changes in European industries (Hanioğlu, 2008: p. 93). In the area of East Macedonia and Kavalla, some small factories appeared at the beginning of 20th century in order to serve local consumer needs. Their activity was further buttressed by some minor changes in the duties in 1907. Import duties further increased and the import of raw materials and machinery became duty-free (Stefanidou, 2007: pp. 183-185).

\subsection{Administrative Reforms}

The Reform Edict of February 1856, besides its far-reaching effects, also restructured the administrative division of the empire along 4 levels: vilayeti, sancak, kaza and nihaye ${ }^{12}$. The new provisional administration further enhanced the position of the governor as representative of the central government. It facilitated state control of the provinces and increased the extracting surplus (Hanioğlu, 2008: pp. 85-86). Kavalla was the capital of its own kaza but belonged to the sancak of Drama and to the vilayeti of Thessaloniki. It was not anymore the administrative center of the area, because Drama was the biggest city after Komotini (Gümülçine) that belonged in Edirne (Adrianople)'s vilayeti. Moreover, Drama was the seat of the local powerful notables known as bey. It was also in the middle of fertile plains, the road to Istanbul passed through and it was more useful as army headquarters because of its proximity to the empire's north borders. Kavalla's medieval walls and castle had become obsolete for modern warfare and the city was not regarded as an important military base anymore. The control of the trade by notables in Drama led European merchants to demand that the kaza of Kavalla be controlled by Thessaloniki or that Kavalla become the capital of the sancak instead of Drama. The Ottoman authorities resisted these demands and until 1912, Kavalla was part of Drama's sancak. Due to the bourgeoning commercial community, a court that specialized in commercial law was set up in Kavalla in 1858 (Stefanidou, 2007: pp. 144-147).

The effects of the Rose Chamber Edict of 1839 included guarantees for a range of individual rights and a fairer tax system, such as life and property rights and abolition of tax farming, also known as Malikane (Hanioğlu, 2008: pp. 6-7, 72). Among others, these reforms demanded of each community to create its own representative committee responsible for its internal affairs. This committee would also mediate among its members and with the state. Although the small number of Christians in Kavalla did not facilitate the implementation of these reforms, in 1864 a committee appeared with the local religious leader as its head (Stefanidou, 2007: p. 150). This demand was in a process of adoption western state structures in the region in order to secure the elites participation in the local power structures: a notion that would enhance the legitimacy of the ottoman state in the ground with the elites' support as a medium in order the masses to be reached (Binder-Iijima \& Kraft, 2010: p. 3).

\subsection{Land Ownership and Taxation}

The norm in land ownership and taxation, which were inextricably linked, was the Timar system. It functioned as an autonomous financial unit with a balanced budget. This meant that state would not to have to pay salaries to local officials and soldiers, especially in the cavalry. Very often, it coexisted with the Malikane system for important sources of revenue but gradually the Malikane became the standard system in tax ownership and taxation. A source for revenue was auctioned by the state to the highest bidder. This was initially on an annual basis but gradually it was extended for the duration of the lessor's life. In certain cases, the lessors' descendants continued to exploit the source of revenue and to establish hereditary rights. Although the Malikâne increased temporarily the state's revenues, it led to the exhaustion of new sources of revenue and increased the state's need to borrow money (Hanioğlu, 2008: p. 21) (Pamuk, 2000: p. 200).

\footnotetext{
${ }^{12}$ Vilayeti was the equivalent of a region, sancak of a province, kaza of a municipality and nihaye of a village or neighbourhood.
} 
Big landholdings in East Macedonia, known as çiftlik, were not so widespread in comparison to the rest of the Balkans. They covered $24 \%$ of the arable land while the rest was shared between medium and small farms (Stefanidou, 2007: p. 155). The size of the landholdings influenced also the kind of products that were cultivated. The big landowners chose cereals and husbandry. The owners of small and medium sized farms preferred to grow commercialized goods such as cotton and tobacco because, although they were more labor-intensive, they had a higher return per acre. The cultivation of those goods in large landholdings would have demanded big numbers of specialized workers not available because of the chronic workforce scarcity in the Ottoman Empire. Moreover, making the products available, especially cereals and dairy products, at fixed or below market prices to the state for the capital and other urban centers did not allow small and medium-size farms big profit margins. Sometimes they were not even able to cover their expenses. In contrast big landowners were able to survive low prices by increasing production and by using their political connections within central authority to secure higher prices (Hanioğlu, 2008: p. 23).

Large landholdings were to be found in the plains north of Kavalla, where the big cities of Serres and Drama were. In contrast, in the hilly and mountainous area around Kavalla it would be easier for owners of smaller farms to prosper. In contrast to tenant farmers, who did not have any property rights, and agricultural workers, the owners of small landholdings secured a higher income especially if they could cultivate commercialized goods that could be sold at higher prices in the market. Kavalla and the surrounding area allowed them to switch the agricultural production. Nevertheless, bad harvests, regular and additional taxes and the lack of agricultural credit institutions often forced them to mortgage their land so as to be able to borrow money from tobacco merchants, middlemen, moneylenders and trading firms such as Regie. When they could not pay their debts, they worked as seasonal workers in cities and sometimes moved permanently there. This was a source for tobacco workers in Kavalla and it prevented them from a need to emigrate abroad, as was the case in other places in the Balkans. Moreover, these dangers may have undermined the small and medium ownership of land and led to the creation of large estates (Stefanidou, 2007: pp. 155-157) (Pamuk, 2000: p. 222). The production of tobacco increased constantly throughout the period of 1839-1913 and replaced other less-commercialized goods such as cereals, cotton and dairy products because the farmers in Kavalla were free to sell their crops to the highest bidder. In contrast, the neighboring kaza of Eleftheroupoli and Chrisoupoli had to sell their tobacco and cotton production for the capital's market at lower, usually, prices. The increase in production did not come with an improvement in the means of production which remained rather primitive. The local farmers were reluctant to use new seeds and only towards the end of the period does one see broad use of chemical fertilizers. Moreover, the establishment of Regie as the tobacco state monopoly in 1884 led producers to increase production at the expense of quality. This was a consequence of Regie's policy of relegating various tobacco qualities into lower categories in order to reduce the prices. Tobacco exports continued due to its supreme quality, the result of area's climatic conditions and farmers' specialization in its cultivation (Stefanidou, 2007: pp. 189-191).

\subsection{Transportation Network}

Along with the area's special characteristics and labor that specialized in the cultivation of commercialized products, its transportation network was a fundamental factor in the incorporation of a city like Kavalla and its surrounding area into the world economy. The roads were primitive but transport was facilitated by the largely level land. After the 1890s, the railway line connecting Thessaloniki with Istanbul was completed but went through Drama in the north and Kavalla never had a railway connection (Stefanidou, 2007: pp. 159-160).

The main reason for its growth, however, was the comparative advantage of its port. The transportation cost was lower for maritime trade and was further reduced by the spread of steamboats because they were larger and not dependent on maritime conditions. Companies, such as Austria's "Lloyd”, France's "Messageries Imperiales Maritimes" and "Marc Fraissinet" had been using the port regularly since the 1840s until it gradually became a major harbor for other shipping lines as well. As French and Austrian trading firms were obliged to use shipping lines from their own countries, French and Austrian ships ranked first in trade volume from the port (Stefanidou, 2007: pp. 161-164).

The increase in maritime trade made necessary to set up consulates and sub-consulates in the city that would facilitate the trade activities of their merchants and defend their interests. Austria, France, England, Russia and Germany all had sub-consuls in the city. Although their presence was not permanent there was usually an adequate consular representation in the port (Stefanidou, 2007: pp. 166-168). Very often, the representation of those 
countries was assigned to powerful local merchants, usually Christians while Greek and French were the lingua franca for trade activities in the Balkans (Hanioğlu, 2008: pp. 37-38) (Pamuk, 2000: p. 201).

\subsection{Changes in Social Structure}

As the population increased in the region, Kavalla itself doubled its population in less than 40 years, reaching 8000 in the 1870s. More than 2000 came as seasonal workers in the summer and in 190532000 people leaved in the city. Although the majority of the population were Muslims, especially in the neighboring hinterland, the number of Christians, Jews and Europeans constantly grew and eventually accounted for 30\% of the population in 1905 (Stefanidou, 2007: pp. 125, 130, 135). In the same period the empire lost part of its territory in the northern Balkans: Large number of Muslims from the Balkans moved to the south during the Ottoman-Russian war in 1878 and especially in the area around Komotini (Gümülcine) and the Rhodope Mountains (McCarthy, 1995: p. 77). Ottoman claims of the slaughter of 7000 local Muslims, by the invading Bulgarian army in Eastern Macedonia during the Balkan Wars indicate that this was a region with large Muslim and Christian populations (McCarthy, 1995: p. 145) (Yavuz, 2013: p. 45).

The increased trade activity, the incorporation of the local market in the world economy, the specialization of the local agricultural sector in commercialized goods (mostly cotton and tobacco) created a local bourgeoisie which included tobacco merchants, local notables, administrative officials, representatives of foreign consular authorities, bankers, moneylenders and landowners. When the city became part of the Greek state, the city and the area had undergone rapid urbanization and a cosmopolitan commercial society had emerged. It had most of the tobacco trading firms and the largest population of tobacco workers in the region. The ethnoreligious divisions were apparent in the upper classes as well: the city's Muslims were usually big landowners, administrative officials and lessors of state's revenue. Christians and Jews, who were Ottoman or European subjects, were employed in the trade sector and in the consulates of the city. Until the end of the 1850s, the powerful local notables mediated between the trade firms and the producers but lost their role as middle men and the manufacture and trade of tobacco was increasingly controlled by foreign trading firms (Stefanidou, 2007: pp. 171, 192-193, 196-197). Since the reforms of 1830s, the equality of religions was accepted, at least nominally, as a principle for recruitment but the vast majority of state officials would be Muslims (Pippidi, 2010: p. 117).

The urbanization of the area and the growth of the city affected middle class numbers as well. Most of them were employed in the trade firms and in the city's vibrant commercial sector (Stefanidou, 2007: p. 202). Muhammad Ali's school (külliye) also attracted a large number of Muslim students from all over the empire and the funding of the school was secured through the system of vakf $f^{3}$. Members of the religious, administrative and military elite were educated in schools like this and were then employed in state and religious institutions (Hanioğlu, 2008: p. 21).

The number of tobacco workers also increased throughout the period. In the beginning, these were peasants from the surrounding area who chose to move to the city and work in the warehouses to supplement their income. Gradually, they started to settle permanently in the city and their links with the farming hinterland weakened (Stefanidou, 2007: p. 140). They were a big part of the city's population and they finally founded worker's unions (1909) in order to negotiate their earnings. Although their wage was higher than that of other workers, the seasonal character of their job did not allow them to earn a decent living. These problems led them to support the revolution of the Young Turks in 1908 while the Federation spread its message to the city's workers. The Young Turks revolt had raised high hopes that a more democratic regime would be established so as to defend the interests of the lower classes, the peasants and the workers (Yavuz, 2013: p. 31). The Federation, one of the first workers' unions in the empire, was founded in Thessaloniki and was instrumental in raising the class awareness of the emergent working class of the empire. Nevertheless, the CUP regime drafted in 1909 a new Law on Strikes in order to protect the social peace that was undermined from the industrialization of Ottoman Empire and the consequent radicalization of its working class.

Clubs for the upper classes also made their appearance in 1910. In 1912, a branch of CUP was founded, which included as members all upper class Muslims and 4 Greeks although the Greek state and the Patriarchate demanded of Greeks not to join the CUP (Hacisalihoğlu, 2013: p. 105). A branch of the Ottoman Liberal Union Party (LUP) was also founded but it was much less popular because of its association with the Federation in

\footnotetext{
${ }^{13}$ In this system, specific sources of revenue could be attached to religious and educational institutions which did not have to pay taxes but a fee. Connecting productive activities to institutions like these was a widespread form of tax evasion in the Ottoman Empire.
} 
Thessaloniki. The Greek consulate exerted pressure on local Christians, almost all of whom were Greek-speaking, to create clubs and associations which would advocate the union of the area with Greece but the Christian upper class was reluctant to act in ways that would harm their commercial interests (Stefanidou, 2007: pp. 205-209) (Hanioğlu, 2008: p. 136). It was common for non-Muslim merchants, bureaucrats, and members of the upper middle class in the commercialized regions to embrace the political ideology of Ottomanism which stressed the common elements within the multi-cultural Ottoman society. It attempted, with limited success, to counter the spreading message of nationalism by using loyalty to the Sultan as the main characteristic of a new political collective identity (Hanioğlu, 2008: pp. 107, 167) (von Sivers, 2013: p. xxxii).

In summary, the first trade agreements between the Ottoman Empire and the Great Powers in 1840s allowed Kavalla and its hinterland to reorient itself as an exporter of raw material for European industries. This increased the amount of wealth in the region, its urbanization and led to the rise of strata associated with modern economies: a vast working class, a significant middle class, and an increasingly powerful bourgeoisie with an autonomous presence in social life but in alliance with the state bureaucrats and the big landowners. While those took place, the simultaneous state reforms in the 19th century further increased its presence in social reality, invested in the improvement of transportation networks and attempted to increase its revenues from the modernization of the economy.

\section{Conclusion}

The growth of Kavalla as a port for tobacco export can only be seen in relation with the Ottoman state's radical program of modernization. This growth could not have taken place in the context of an early modern social order and economic policy. The drastic effects of modernity in a society, seen by its contemporaries in Europe as "traditional", "backward" and "obsolete", did not only harm the previous social order but also created a multicultural and multinational cosmopolitan society in the 19th century at the periphery of the capitalist world. The empire's position in the periphery and the privileged conditions in some of its regions purred financial growth through the export of commercialized agricultural products.

The question of whether the state intended to reorient the Ottoman economy as an exporter of agricultural products and raw materials couldn't be easily answered. Ottoman's ruling class' vague ideas about economic modernization prevented it from following a coherent financial policy. Its main principles were the increase of state revenues and the creation of a domestic industrial sector because in the 19th century industries and factories were seen as sign of a developed and modern country. But the lack of knowledge and the absence of a coherent plan to achieve these aims left no other option besides blind adherence to the advice of foreign financial advisors, mainly from France and England. The free-market liberal economy that emerged had several consequences. Although it increased the trade deficit and the pressure to the guild's manufacture activities, it also boosted the export of agricultural products in several regions of the empire leading to the growth of cities such as Thessaloniki, Izmir and Istanbul. The lack of insurgencies in the Balkans between 1821 and 1876 might be seen as related to the region's financial growth and, correspondingly, to the reduced appeal of nationalism in its Christian communities (von Sivers, 2013: p. xxxiii).

This growth took place by state policies that changed trade practices. Gradually during the 19th century areas such as the kaza of Kavalla did not have to sell their agricultural production at fixed prices to supply the capital and could make a bigger part of their production available for exports. The ban on the export of important agricultural products such as cereals was also raised, custom duties for imports and exports were lowered and both foreign and Ottoman merchants were liable to the same taxes. These changes facilitated the increase of exports but the state failed to fully benefit from its growth because of corruption among local administrative officials and an inefficient taxing system. Kavalla's growth during the 19th and early 20th centuries, from an unimportant regional city to one of the biggest exporting ports of the Balkans, could only be seen as a product of the empire's attempt to modernize its structures and its subsequent economic incorporation into the global economy of emerging capitalism.

\section{References}

Binder-Iijima, E., \& Kraft, E. (2010). The Making of States: Constitutional Monarchies in the Balkans. In A. Mungiu-Pippidi, \& W. van Meurs (Eds.), Ottomans into Europeans: State and Institution-Building in South Eastern Europe (pp. 1-30). London: Hurst \& Company. 
French-Ottoman Trade Treaty (1839). (n.d.).

Hacısalihoğlu, M. (2013). The Young Turk Policy in Macedonia; Cause of the Balkan Wars? In M. Yavuz, \& I. Blumi (Eds.), War and Nationalism, 1912-1913, and Their Sociopolitical Implications (pp. 100-132). Salt Lake City: The University of Utah Press.

Hanioğlu, M. (2008). A Brief History of the Ottoman Empire. Princeton and Oxford: Princeton University Press.

Hershlag, Z. Y. (1968). Turkey, the Challenge of Growth. Leiden: E.J. Brill.

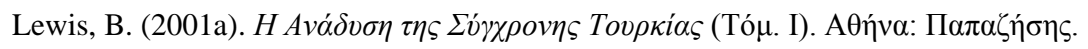

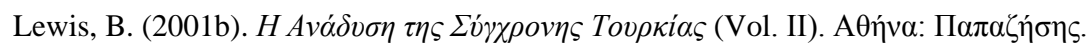

McCarthy, J. (1995). The Ethnic Cleansing of Ottoman Muslims 1821-1922. New Jersey: The Darwin Press, INC. Princeton.

Pamuk, Ş. (2000). A monetary History of the Ottoman Empire. Cambridge: Cambridge University Press.

Pippidi, A. (2010). The Development of an Administrative Class in South-East Europe. In A. Mungiu-Pippidi, \& W. van Meurs (Eds.), Ottomans into European: State and Institution-Building in South Eastern Europe (pp. 111-134). London: Hurst \& Company.

Quataert, D. (1994). The Age of Reforms, 1812-1914. In D. Quataert, \& H. Inalcik (Eds.), An Economic and Social History of the Ottoman Empire, 1600-1914 (Vol. II). Cambridge: Cambridge University Press.

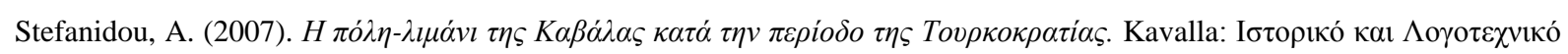

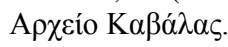

von Sivers, P. (2013). Preface; the Rise of Balkan Nationalism within the Triangle of the Ottoman, Austrian and Russian Empires, 1800-1878. In M. Yavuz, \& I. Blumi (Eds.), War and Nationalism; the Balkan Wars, 1912-1913, and Their Sociopolitical Implications (pp. xxiii-xxxix). Salt Lake City: The University of Utah Press.

Yavuz, M. (2013). Warfare and Nationalism; the Balkan Wars as a Catalyst for Homogenization. In M. Yavuz, \& I. Blumi (Eds.), Warfare and Nationalism; the Balkan Wars, 1912-1913, and Their Sociopolitical Implications (pp. 31-85). Salt Lake City: The Utah University Press. 